ensis. Still others, while but little more widely differentiated are considered as distinct species; there are many of these but a few will answer for illustration, Eurygaster alternatus and E. maurus, Neottiglossa undata and $N$. in. flexa, Triphleps insidiosus and $T$. niger, Cixius pini and C. stigmaticus, and Deltocephalus debilis and D. abdominalis. The first series may probably have been introduced from one faunal region to another, but the two latter series naturally lead us to look back to a common preglacial ancestor whose descendants in the second series have, in accomodating themselves to their changing environments, undergone a similar modification in the different re- gions, or have exhibited greater stability in resisting these changes. In the third series the change has been a littleso metimes only a very little-more perceptable.

In Psyche v. 5. p. 211-2I4, Mr. C. W. Woodworth, in an interesting and instructive paper on the genera of the North American typhlocybini, says he has not recognized a single European species of the group from this country; he seems to have been unaware of the fact that Kybos smaragdulus occurs not only throughout the northern states and Canada but even as far west as California from whence I have recently received examples from Mr. Coquillett.

\title{
SYNOPSIS OF THE ODONATA OF NORTH AMERICA. No. I.
} By hermanN AUgUSt hAgen, CAMBridge, mass.

Since I86I, when my Synopsis was published by the Smithsonian Institution, I have, of course, studied these Odonata. The specimens described in my first work were never less than three years old, mostly over twenty, some nearly sixty. During my residence here I have always tried to compare fresh specimens, and if possible to describe living ones. There are very few of which the old types could not be studied again with new specimens. Of the species described since $\mathrm{I} 86 \mathrm{I}$ I have seen the types or had sufficient information by the authors themselves. The localities are given here always as complete and detailed as possible.
Tribe I. Agrionina.

Eyes distant; antennae four-jointed; wings equal; abdomen cylindrical, slender; accessory male-genitals with the anterior hamulus connate ; penis and vesicula separated; female genitals vaginate.

\section{Sub-family. Calopterygina.}

Antecubital veins numerous.

Calopteryx Leach.

Wings broad, densely reticulated; pterostigma absent in the male; in the female absent, or very small, or irregular, areolate; basal space without transverse veins; quadrangular space 
straight; legs long, densely spinose; appendages of the male forcipate, of the same shape in all species.

I have given a preliminary notice on the previous stages, Compt. rend. soc. ent. Belge., I880, May I ; the figures are not yet published.

Larvae slender, elongate; the basal joint of the antennae very strong and twice as long as the other six together; mask elongate, narrow, very dilated on tip, split en losange far beyond the base of the palpi; occiput on each side with a prominent spine; legs long, slender, abdomen on tip with three flat pointed gills, the intermediate shorter; there are rectal gills, and stigmata as commonly.

The genus Calopteryx largely represented in the northern boreal and temperate zone nowhere passes to the south beyond the 3 oth degree. The excellent study of De Selys has shown that the species are few, but the varieties and races rather numerous. For the old world three species: C. virgo, C. splen. dens and $C$. haemorhoidalis live in Europe and on the northern border of Africa. The first two are to be found also in the northern and western parts of Asia. For the eastern part of Asia and Japan, three species are known, $C$. atrata, $C$. cornelia and $C$. grandaeva. None of these species are found in the new world. De Selys (Odonates de l'Asie mineure, I887. Ann. soc. entom. Belg.) has given a splendid study of Calopteryx. The important race Corientalis Selys, p. 40, he considers as proving that $C$. syriaca is a race of $C$. splendens, the more so as some large males Synop. 3 Add., p 7 . seem to support this opinion. He was sorry to have seen only the male. Mr. E. Eichwald (Reise auf dem kaspischen meere, r837, v. 2, p. 272) has described the female. In Lakwish Mingrelia he saw many Odonata metallic blue and metallic green. He believed the latter to be a new species, Agrion colchicius (sic!) aeneo viridis, thorace altiore, sulcis inter areas aeneo-virides nigris notato, inferne nebuloso-coerulea, trunco superne aeneo-viridi, ultimis segmentis minimis tumidioribus, flavidis; alis omnibus aequalibus, medio posticis dilatatis, apicibus rotundatis, aenea viridi-nigrescentibus, omnibus antice macula marginali nivea notatis ; pedibus nigris, subtus nebuloso-coeruleis, antice longis setis piliformibus instructis; venis alarum parvis (cf Stettin. ent. zeitung, r $856, \mathrm{p} \cdot 365$ ).

Group I. Wings narrow; the hind margin parallel to the front margin. (Sylphis Hagen.)

\section{i. Calopteryx angustipennis.}

Sylphis angustipennis, male. Selys Monogr. Cal. 21,2 ; Synops. Cal. 9,2 ; 4 Add. 6, . - Walker Catal. Br. mus. 590,2 - Hagen Syn. Neur. N. A. 56,1 ; Stett. ent. zeitung, v. 24, 372,24 . Proc. Bost. soc. nat. hist. v. I6, 363,5 I (the two last on Abbot's figure); Syn. Odon. N. A. 20, IMcLachlan Ent. mo. mag. v. IO, 227 female, Abbot's type.

Sylphis elegans, female. Selys Monogr. Cal. 20, I ; pl. 2, f. I ; Synops. 
Cal. 9, r ; Walker Catal. Br. mus. 590,r. Male (adult ?) ; known only by short diagnosis made in $185 \mathrm{I}$ by De Selys and by Abbot's figure, both compared by myself and declared to be similar to the female described as S. elegans. Brassy green, labrum and labium and the second joint of the antennae pale yellow, two sharp tubercles behind the occiput; legs very long, spines short, black; appendages similar to $C$. virgo; wings very narrow, pointed, the hind wings eight $\mathrm{mm}$. broad; hyaline, pale greenish, probably also the reticulation; sector principal partly connected with the mediana; 29 antecubitals.

Female, semi-adult; metallic green; labium pale, labrum pale yellow, a little black in the middle of the margin; epistoma metallic green in the middle; sides of the mouth pale yellow head metallic green above, with a yellow spot before the ocelli; second and third joint yellow, of nearly equal length; tubercle on the occiput sharp; colors of the thorax not finished : dorsum metallic green in the middle, reddishbrown to the humeral suture, which is fine and yellow; mesothoracic crista black; sides metallic blue between two lateral yellow bands; below and around the legs yellow; axillary callus steelblue; legs brown, darker to the knees, thin and very long, the hind legs $26 \mathrm{~mm}$. reaching nearly to the end of the fifth abdominal segment; spines shorter and not so frequent as commonly; wings long, a little pointed on tip, narrow; front wings, $7 \frac{1}{2} \mathrm{~mm}$. broad on the nodus; hind wings $6 \frac{1}{2} \mathrm{~mm}$. a little yellowish; reticulation pale reddish ; costa steel-blue; 30 antecubitals; $S$ in quadrangular space; sector principal very near to the mediana, but not entirely connected; everywhere only one series of cells between two veins; no pterostigma; abdomen metallic green, below blackish; only the five basal segments retained.

Female, adult. Brassy green, shining; labium yellow, blackish in middle ; labrum yellow; middle of front-margin finely black, also an impressed basal spot; head and epistoma brassy green; second joint of antenna yellow; thorax brassy green; crista black; humeral suture finely yellow; sides brassy green after the second suture, between the legs, and below dull yellowish; legs black; wings long, a little broader, front wings $9 \mathrm{~mm}$., hind wings $8 \mathrm{~mm}$. broad near the nodus; apex more rounded; a little yellowish, more colored at the base; reticulation black; costa and axillary callus brassy green; 25 antecubitals; 6 to 5 in quadrangular space; sector principal entirely connected with mediana shortly after its origin; no pterostigma; abdomen brassy green, black below; last segments darker brassy, with a white longitudinal band on the three apical ones, broader on the penultimate, smaller on the segment before and on the last, ending on the apical carina; appendages yellow, sharp ; sides of last segments and valves yellow, with black palpus.

$\begin{array}{lccc} & \text { Male. } & \text { Female } & \text { Female, adult. } \\ \text { Length, } & 67 & 5^{2} & 56 \\ \text { Abdomen, } & 56 & 43 & 43 \\ \text { Exp. al.. } & 32 & 78 & 78\end{array}$


HAв. Briar Creek, Georgia, rare, April I8, Abbot; male type in the Brit. mus. (figured); female Dublin Mus. r. soc. (not seen by me); female type of $S$. elegans out of Berlin mus., bought by me, 1835 , with the label written by Count Hoffmansegg, "patria ignota." There was in 1845 no other specimen in the Berlin mus. Female adult Bee Spring, Kentucky, June, by Frank G. Sanborn; both females now in the Cambridge (mus.).

The insufficient material leaves this species doubtful. De Selys and myself have studied the male type in the British museum, and McLachlan the female in Dublin, which he declares to belong to $C$. angustipennis. The female of $S$. elegans is rather young. The character formerly urged by $\mathrm{De}$ Selys that the principal sector is connected with the mediana in $S$. angustipennis, and separated in S.elegans has been recognized as not so striking. The male type shows the sector very near but separated from the mediana; but male and female are probably both young specimens. The female adult from Kentucky has the sector principal connected with the mediana. This female has the wings a little broader. The difference of this female from $C$. amata is shown by the lack of the pterostigma, by the yellow appendages, black in $C$. amata, and the white band on the last three segments. The differences of the female $S$. elegans may be considered as belonging to its younger age. With our actual knowledge of Calopteryx of the whole world there $i_{\mathrm{s}}$ no doubt that $S$. elegans is a North American species.

2. Calopteryx amata Hagen, nov. spec.

Male, brassy blue; head bronze, brassy green near occiput, which has on each side a sharp tubercle; epistoma bronze; second joint of antenna yellow; labrum yellow, a basal spot and margin around black; labium yellow, middle part black; thorax brassy blue; dorsal crista black, sides brassy green; around the coxae yellow; a small band below on the first suture and another along the ventral border yellow; legs long, black; hind tibia I I mm.; abdomen brassy blue, below black; appendages of the typical shape, black; the inferiors below at the base reddish; wings narrow, $9 \mathrm{~mm}$. broad at the nodus, with a yellowish tinge, stronger at the base; costa and axillary callus steel-blue, reticulation black, not very dense; no pterostigma; hind wings brown on the tip for the fourth part of their length, the internal border of the brown straight but not well defined; the tip of the brown spot sometimes brighter; antecubitals about 30 ; in the quadrangular space 3 to 5 .

Female, brassy green; head similar but the yellow labium only with a triangular black basal spot, ending on the beginning of the split; thorax brassy green; dorsal crista black, the humeral suture fine yellow; the yellow color below and around the legs more advanced; the band on the first suture longer; the ventral band broader; legs as in the male ; abdomen brassy green, black be- 
low ; last segments darker brassy, with a broad, dorsal, yellowish white, median band on the penultimate segment, and a narrower one on the last, which ends on the sharp apical carina; appendages black, sharp; sides of last segments and valves yellow, with a black palpus; wings similar, with a more yellowish tinge; a very small yellow pterostigma, a little dilated in middle, variable in size, covering two to five cells, sometimes with transversal; between one and two mm. long, or less.

$\begin{array}{lcc} & \text { Male } & \text { Female } \\ \text { Length, } & 55 & 48 \\ \text { Abdomen, } & 45 & 38 \\ \text { Exp. al., } & 75 & 75\end{array}$

Hab. Dublin, New Hampshire, near Thorndike pond, $1300 \mathrm{ft}$. above sea level, 2 females, June 18,1887 , and 4 males and 2 females June 22, I 889, by $\mathrm{Mr}$. Louis Cabot.

The hind wings with brown apical color, and the yellow pterostigma of all females are good characters for $C$. amata.

\section{Calopteryx dimidiata.}

Calopteryx dimidiata Burm. Handb. v. 2, 826,16 fem. Selys Monogr. Cal. 24,4. - Syn. Cal. ro,4. - Walker, Catal. Br. mus. 59I, 4. - Hagen, Syn. Neur. N. A. 56, I ; Stett. ent. zeitung, v. $24,272,25$; Proc. Bost. soc. nat. hist. v. 16, 364,52 (both on Abbot's figure).

Calopteryx cognata Ramb. Neur. 222,6 female.

Caloptery'x syriaca Ramb. Neur. 223,9 note, male.

Male, metallic blue, on thorax and end of abdomen changing partly to green; labium, head below and antennae black; labrum and epistoma metallic blue, shining; tubercle on occiput sharp ; crista of the thorax, all sutures and below black; legs black; abdomen black below; appendages of the typical shape, black; wings narrow, hyaline with light yellowish tinge, the apical part black, with the inner border of the black straight; reticulation black, costa steel blue; front wings 22 to 27 antecubitals; in the quadrangular space 6 to 8 .

Female adult, metallic green, head and prothorax sometimes changing to blue; colors as on the male; thorax more evident in younger specimens with the second suture and the ventral border and below yellowish: legs and the more numerous spines black; hind legs reaching to the beginning of the fourth segment; abdomen very slender, metallic green, last segment dark; below entirely black, appendages black; the lateral border below the appendages with 4 to 5 small teeth; wings hyaline, very slightly yellowish; apex of hind wings brown in the last quarter, the inner margin straight; apex of front wings brownish, not so well defined; pterostigma large, white, dilated in middle, crossed by some transversals; reticulation black; the costa and axillary callus steel blue; the sinus before the wing-base with the posterior border straight; 20 to 25 antecubitals; quadrangular space 4 to 6 transversals.

The young females have the wings hyaline, with a little yellowish tinge, not brown on tips, except a light 
brownish shade on hind wings.

$\begin{array}{lcr} & \text { Male } & \text { Female } \\ \text { Length, } & 50 & 3^{8-45} \\ \text { Abdomen, } & 3^{8} & 3^{1-38} \\ \text { Alar. exp., } & 5^{8} & 57-64\end{array}$

НАв. Kentucky, Burmeister's type ; Georgia, Abbot, 25 April, a couple in the collection of Escher Zollikofer in Zurich; H. K. Morrison, both sexes, many specimens. Palatka, St. John's River, March, O. Sacken, and Appalachicola, Florida, R. Thaxter.

\section{Race Apicalis.}

Calopteryx apicalis Burm. Hdb. v. 2, 227,8. Selys Monogr. Cal. 23,3; Synops. Cal. 9,3. Walk. Catal. Br. mus. 59I,3. Hagen Synop. Neur. N. A. 56,2 ; Synops. Odon. N. A. 2 I, 2 .

The smallest known species; nearly related to $C$. dimidiata but smaller and more slender; male metallic green or blue; labium, head below black; labrum, epistoma, second joint of antenna brassy green or blue; tubercles on occiput very sharp; thorax metallic green or blue, also the parts near abdomen; all sutures black; thorax below yellowish; legs black, hind legs reaching to the fourth segment; abdomen metallic-blue and green; below black; appendages black, similar to $C$. dimidiata; wings narrow, $7 \mathrm{~mm}$. broad, hyaline, the sixth part of the apex black, with inner border straight; reticulation black, costa steel blue; antecubitals 18 to 23 ; quadrangular space 4 to 6 transversals; sinus before the wings with the posterior border sinuated.
Female similar to the male, brassy green; second suture of thorax and the abdominal border, and below yellow; apical segment of the abdomen below with two teeth on the border; wings hyaline without pterostigma or with a very small white one, filling one cell, or a little dilated in three cells; reticulation black, costa steel-blue.

$\begin{array}{lcc} & \text { Male } & \text { Female } \\ \text { Length, } & 43-45 & 43 \\ \text { Abdomen, } & 35-37 & 32 \\ \text { Exp. alar., } & 57 & 57\end{array}$

НАв. Burmeister's types from Philadelphia, Pa.; two males, one female without pterostigma; a couple from the same locality by $\mathrm{Ph}$. R. Uhler with a small pterostigma. Waltham, Mass., July 2r, 1864, by Ph. R. Uhler one male and two females, with a more developed pterostigma; South Reading, Mass., by Frank Stone.

Group 2. Wings dilated; the hind margin visibly rounded.

\section{Calopteryx aequabilis.}

Calopteryx aequabilis Say. Journ. acad. Philad. v. 8., 23,2. Edit. Le Conte, v. 2, p. 405. Hag. Proc. Bost. soc. nat. hist. v. ${ }_{15}, 274,40$.

Male, steel blue or brassy green; head dark, somewhat brassy; tubercles of occiput short, blunt; antennae black ; labrum black: thorax with a fine, wavy, yellow line above the legs; upper appendages black, strong, curvate, the apical half externally with strong spines, internally dilated, after an excision followed by a short tooth; 
inferiors a little shorter, straight, stout, flattened on tip, black; basal half below as well as the last segment, and the part before the valves of the segment bright yellow; legs black; wings hyaline, with yellowish tinge on the base; tip large blackish; fuliginous, occupying the fourth of the length on the front wings, inside ending in a convex but rather suffuse border, occupying the apical third of the hind wings, ending inside in a straight border; venation black, costa steel blue; 26 to 30 antecubitals, 6 in the quadrangle; one series of cells between the veins; postcostal space with nearly simple net of cells.

Female, similar to the male but entirely brassy green; labrum yellow, bordered with black anteriorly and on the basis, with a median triangular spot not reaching the anterior border; second joint of antenna yellow externally; thorax above the base of the legs and along the second suture yellow; abdomen brighter, a dorsal median band, the sides and valves yellow; wings with a stronger vellowish tinge, the apex of the front wings somewhat smoky; third apical part of the hind wings more decidedly smoky, but the inner border suffused, not well defined; pterostigma large, white; feet black.

$\begin{array}{lcc} & \text { Male } & \text { Female } \\ \text { Length, } & 45-60 & 46 \\ \text { Length abd., } & 36-40 & 3^{8} \\ \text { Exp. al., } & 60-68 & 7 \mathrm{I}\end{array}$

Lat. al., Female

Long tib. post., 9 Pterost.
Нaв. Montreal June 12 to $26, \mathrm{Mr}$. H. H. Lyman, male and female ; Quebec, Canada, Mr. Provancher, male ; Norway Maine; Mr. S. I. Smith, male and female ; Bethel, Maine, L. Agassiz, female ; Brookline Mass. and Tyngsboro, Mass., Mr. C. S. Minot; Lawrence, Mass., Mr. J. H. 'Treat, male, I6 specimens.

Race Hudsonica, Hag.

Calopteryx hudsonica, Hag. I 875 . Selys, 4 Add. p. 7, 6 bis.

I have before me only one male, end of abdomen wanting, and two females, one of them a fragment. All are collected by Mr. Barnston at Michipicoten Lake Superior, northern shore.

Until now I have not seen good and sufficient specimens of $C$. aequabilis. I am now of the opinion that $C$. hudsonica is not specifically different from $C$. aequabilis. There are some characters, which may be striking enough to allow it to be considered as a peculiar race. First, it is visibly stronger and more bulky in the thorax, head and abdomen. The dimensions are not larger than the largest ones noted for $C$. aequabilis. The male has the legs pale, which may be due to a lack of development, as I do not find pale legs in a younger male from Norway, Me. The wings are a little stronger tinged; antecubitals 33 . The females are older, the colors more finished. More specimens are needed before a satisfactory conclusion can be reached. The female, described from Hudsons Bay, is similar. Perhaps the C. virgo from Greenland mentioned 
by $\mathrm{O}$. Fabricius, and seen by nobody later, may nevertheless belong to this species, as it is not credible that O. Fabricius could have mistaken this well known and striking insect.

\section{Race Yakima.}

\section{Calopteryx yakima Hag. n. sp.*}

Male, steel blue; head dark; labium and antenna black; tubercles of occiput blunt, short; thorax brassy, sides with a very fine transversal, yellow line above the legs; upper appendages black, strong, curved, with a number of strong spines on the apical half externally, dilated on the same half internally, the dilatation beginning after a tooth, tip rounded; inferiors a little shorter, stout, somewhat flattened, on tip, black; yellow below on basal half; last segment, and the segment before the genital valves yellow below; wings hyaline, base a little yellowish, apical third, a little more on hind wings black, internally cut in a straight line; venation black; costa steel blue; 22 to 30 antecubitals ; 8 transversals in the quadrangular; feet black with long spines.

Female, dark brassy green; labrum black on each side, with an oval yellow transversal spot; second joint of antennae yellow at base externally; sides of thorax with larger yellow bands above the legs, prolonged at the transversal sutures; appendages black, long, pointed; a broad, yellow, dorsal band on the penultimate segment, and a narrower

*Yakima is a nomen proprium as matrona, margarita, sappho, etc. one on the last segment; the final dorsal spine black; valves yellow; wings as in the male, hyaline, more yellowish at the front border to the nodus; apex blackish exactly in the same manner, but not so dark, as all specimens are younger; pterostigma milk-white, $2 \frac{1}{2}$ $\mathrm{mm}$. long.

Нав. At a place called Lone Tree, near the Yakima River in Washington Territory, collected by my assistants and myself, I 3 specimens, 5 of them males; June 30 to July 18,1882 ; all more or less with unfinished colors except two males, which were among the first lot, collected in June.

Long corp. $5^{1} \mathrm{~mm}$.; abdomen 40 ; wings 32 ; tibia post. I I.

The discovery of a species of Caloptervx west of the Rocky Mountains, was very unexpected and rather startling, the more as the species seemed to be different from all known to occur in North America. The nearest eastern species is C. hudsonica from Michipicoten on the northern shore of the Lake Superior and still farther east C. aequabilis. During the last years my attention was drawn to the appearance of western species in the eastern states, namely in the northern part of western New York. One of the most striking of my discoveries is the identity of Cordulia lintneri collected from Center, N. Y., with Lib. vacua Hag. (no descr.) from Saskatchewan and Lake Winnipeg. I cannot but believe that some of the northwestern species pass east by the passage above Missoula, Montana, where the principal rangc of 
the Rocky Mountains ends, and perhaps by the upper parts of the Columbia River. As far as I know, such species are to be found along the northern shore of Lake Superior and then cross over to western New York; such species are, until now, not to be found in eastern Canada or in Maine. Of course when species can come east in such a way, it is possible that some could go west in the same way, and would be. perhaps, modified by the climate. So I found it necessary to compare carefully with C. yakima the C. hudsonica from Michipicoten and $C$. aequabilis.

\section{Calopteryx maculata.}

Agrion maculata Palis. Beauvois $\mathrm{S}_{5}$ pl. 7 , f. 3 (aberratio).

Calopteryx maculata Burm. Hdb. v. 2, 829,17 . Rbr. Neur. 222,5. Selys. Monogr. Cal. 27,5; Synops. Cal. I0,5. Walker, Catal. Br. mus. 592,5. Hagen Synops. Neur. N. A. 57,4; Synops. Odon. N.A. 22,6; Stett. ent. zeitung, v. 24, 372,26; Proc. Bost. soc. nat. hist. v. $15,274,40$; v. $16,364,53$.

Calopteryx opaca Say Journ. acad. Philad. v. 8, 32,2 male.

Calopteryz materna Say Journ. acad. Philad. v. 8, 32, $\mathrm{s}$, fem. (Drury L, pl. $42, \mathrm{f} 2)$.

Calopteryx holosericea Burm. Hdb. v. 2, 828, I3. Rbr. Neur. 226, I4 (erroneously $f$. Java).

Libellula virgo Drury v. I, II 3 pl. 4S, f. 2 ; edit. Westw. I18.

Calopteryx papilionacea Rbr. Neur. 222,6.

Male, metallic blue; head below and second joint of antenna black; labrum black, shining; tubercles of occiput blunt, more or less short; thorax metallic blue, sides and below black; legs black; abdomen metallic blue, the last segments below and the inferior appendages below entirely reddish; wings dilated in the middle, rounded below, black more brown on base, which is on the base more or less hyaline; reticulation very dense.

Adult males sometime occur with irregular hyaline spots, figured by Palisot Beauvois as his Agr. maculata.

Male junior, similar, but the wings hyaline, pale gray; axillary callus and costa steel-blue.

Female, head and thorax metallic green or brown; abdomen brassy brown; last three segments with a pale yellowish band, broader on the penultimate; black below; wings very variable in shape and color; sometimes as broad as third of the length; always a milkwhite pterostigma, quadrangular, the corners rounded, $2 \mathrm{~mm}$. long, or very large oval, $4 \mathrm{~mm}$. long; color as the younger males, with a brownish tinge, darker along the basal half of the costa and on the apex of the hind wings; sometimes darker brown with the apical quarter of the hind wings or also the front wings dark brown; the darkest colors in the south from S. Carolina to Florida; the northern specimens paler.

Antecubitals less than 30, rarely I9; quadrangular space 5 to 9 transversals, or a few more.

$\begin{array}{lcr} & \text { Male } & \text { Female } \\ \text { Length, } & 44-48 & 3^{2-50} \\ \text { Abdomen, } & 34-40 & 30-32 \\ \text { Expan. alar. } & 50-66 & 54-66\end{array}$


Нав. Common, nearly everywhere. I have seen the types of Burmeister, Rambur, Selys and Say in Harris collection. Canada, Quebec; Maine, Norway; Massachusetts, everywhere ; New York; Wisconsin, Upper Wisconsin River; Illinois; Ohio ; Maryland; Kentucky ; Kansas; N. Carolina ; S. Carolina; Georgia; Washington, D. C. ; Tennessee; Florida; Texas.

The species described will perhaps have to be reduced to four. The material known for $C$. angustipennis is decidedly not adequate; if a larger num. ber should prove the differences given for C. amata not persistent, the two spe- cies will belong together. I acknowledge this to be possible; after our actual knowledge the union can not be proposed on mere guessing.

C. dimidiata and $C$. apicalis have to be accepted as belonging to the same species.

C. aequabilis has nothing to do with $C$. dimidiata. C. maculata is very striking, and surely different from all the other species.

C. splendens Hagen Synops. Neur. N. A. 58.6 is surely not to be found here. It was quoted after a specimen in Escher Zollikofer's collection, said to have been sent from Georgia by Abbot.

\section{A CONTRIBUTION TOWARDS A KNOWLEDGE OF TERMITES. ${ }^{1}$} By BATtista gRASSi, CATANIA.

We will begin with Calotermes flavicollis. I am able to state that individuals (young nymphs) provided with short wings, ${ }^{2}$ wing pad of Hagen, can be developed into supplementary kings and queens.

These supplementary kings and queens are:

I. Individuals (youngest larvae of Fritz Müller) which are not developed enough to be considered either as soldiers (in Calotermes there are no workers) or as sexually mature forms

Translated from Entomologische Nachrichten, Juli, 1889, 15 Jahrg, No. 14, p. 213-219.

2 I use this term in the Fritz Müller sense, for the first formation of the wing, just as wing-stump (scale) is used for what remains after the wing is torn off. with fully developed wings (winged individuals of Fritz Müller.)

2. Sexually mature larvae and nymphs with longer or shorter wings. I have some supplementary kings and queens two and three years of age which show the same characters that they did at the time of their election, and consequently they do not show the slightest development of the wings, the color of the body alone has become darker (yellowish brown).

The sexual organs of the supplementary kings and queens are identical with those of the true kings and queens. The anal appendages which are always present in the true queen are often 

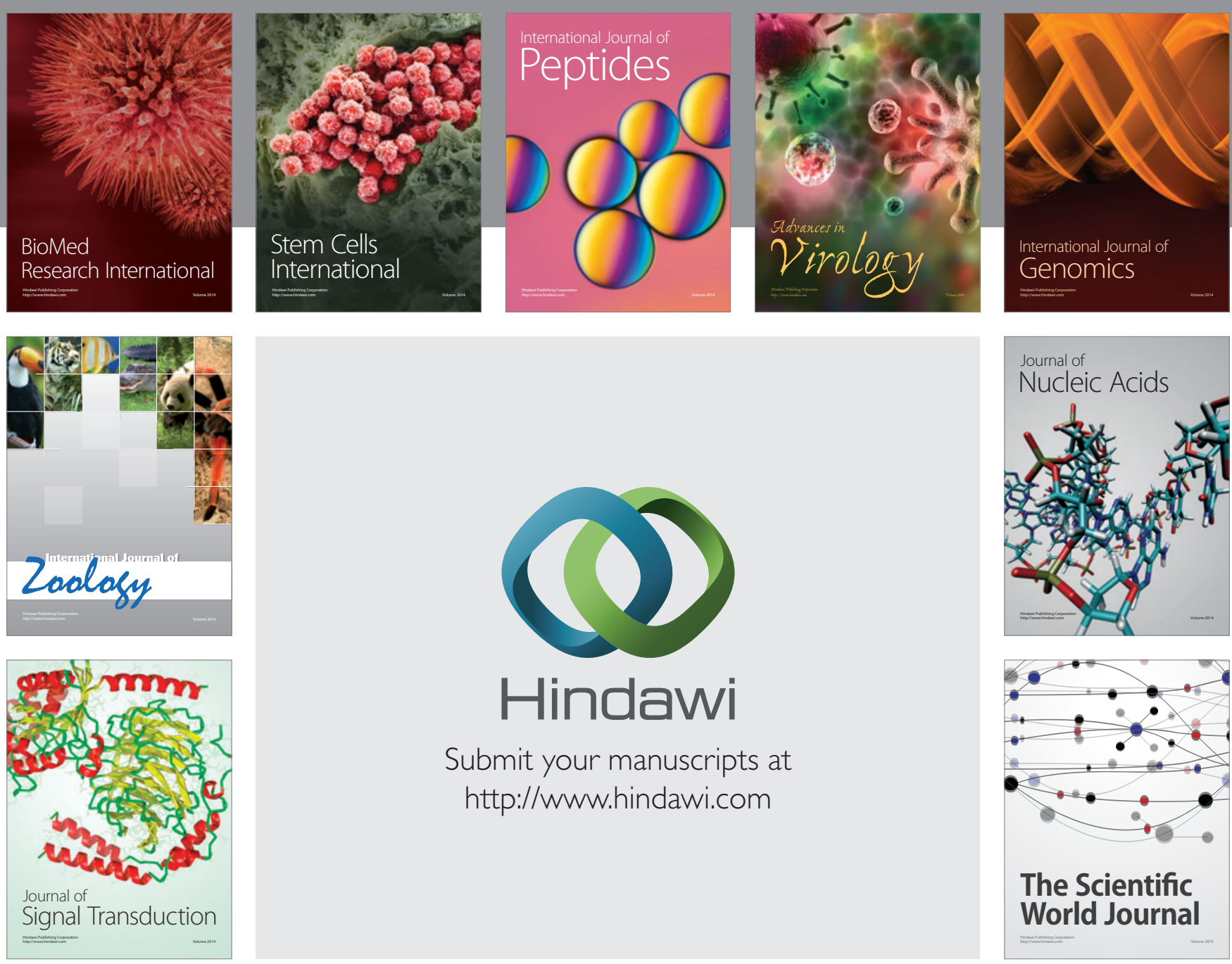

Submit your manuscripts at

http://www.hindawi.com
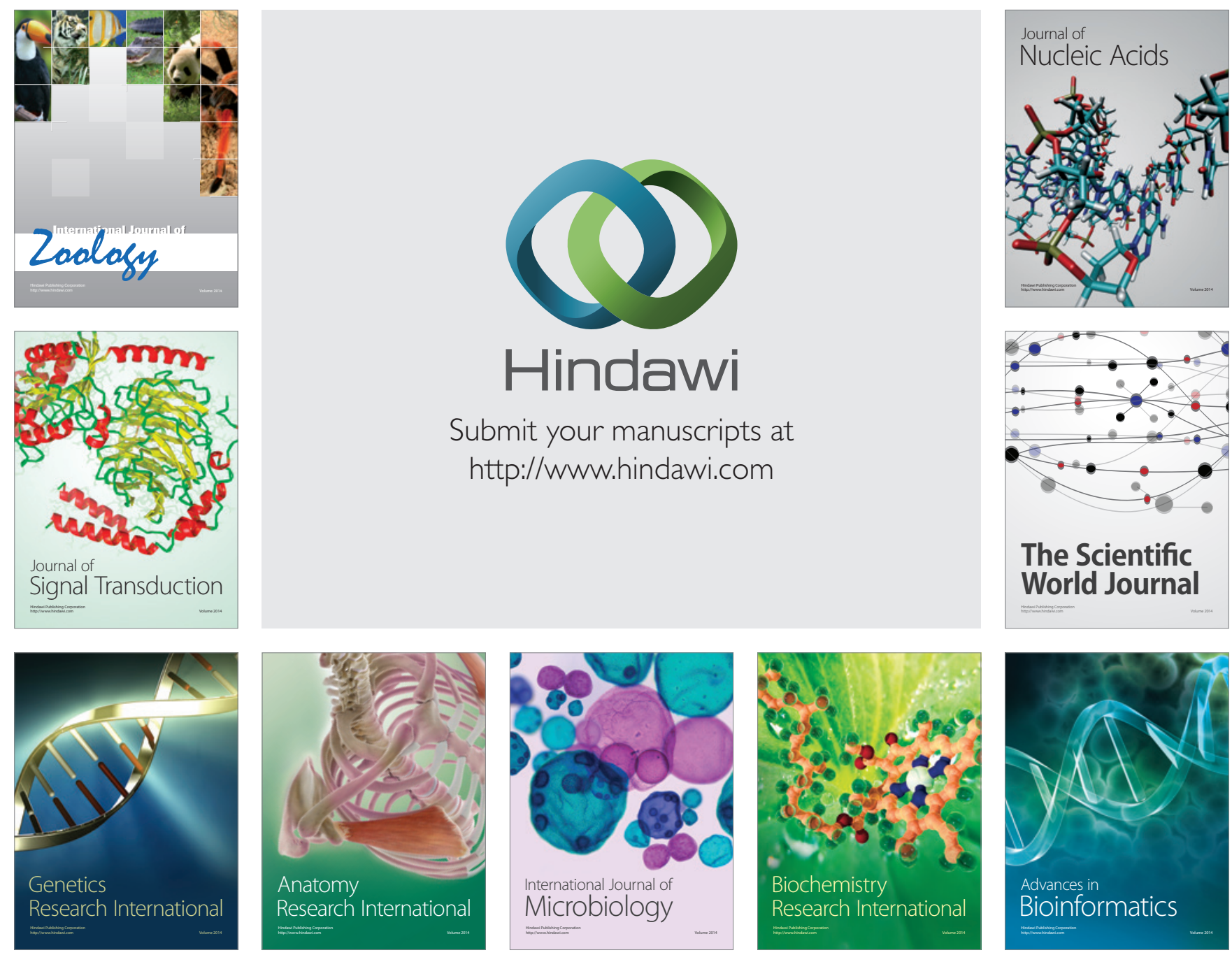

The Scientific World Journal
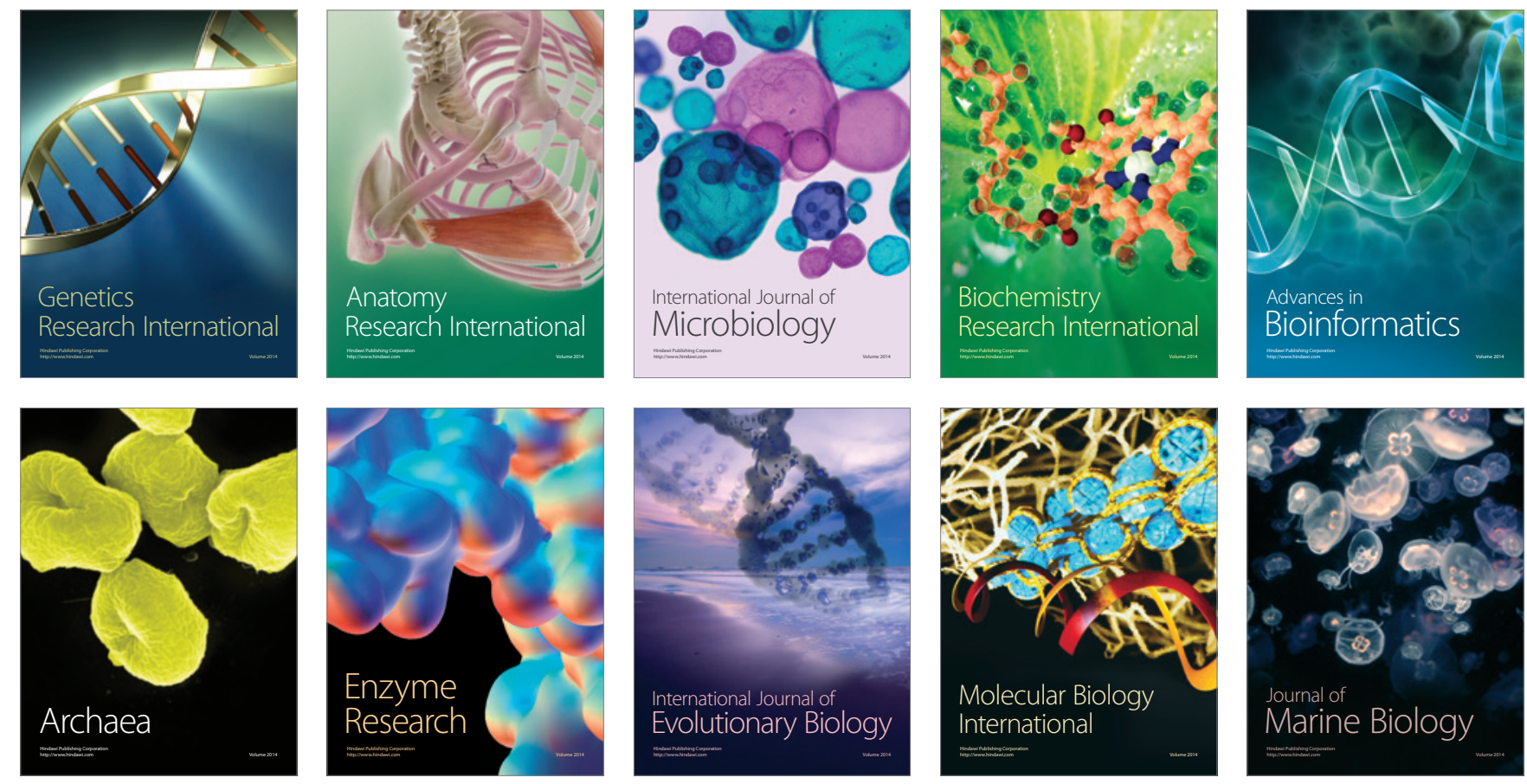